\title{
The Effect of NDVI and NDBI on Land Surface Temperature in Cirebon City 2015 and 2019
}

\author{
Cantika Liviona D.A. , Ratna Saraswati, Adi Wibowo \\ Department of Geography, Faculty Mathematics and Natural Sciences, University of Indonesia, \\ Depok
}

\begin{abstract}
The development of a city is essentially influenced by the growth and development of the population, where the city as a physical container of urban community activity. Cirebon City is experiencing rapid regional development, such as the access of the Cipali highway which is connected directly to DKI Jakarta (Capital City). Therefore, the city of Cirebon has a relatively high connectivity where the cities cause a movement of people and goods to the city of Cirebon more quickly and more intensely. Since the middle of the 20th century, human activity has been closely linked to global warming that occurred from observations of rising global average temperatures. This study aims to analyze changes in LST in the city of Cirebon. LST was obtained from Landsat images and analysis spatially and temporally. This study also analyzes the effect of NDVI and NDBI with LST in 2015 and 2019 with 93 sample points selected by stratified random sampling and using multiple linear regression methods. Analysis of LST changes is done by overlay method. The analysis showed spatially the city center has a very high temperature. LST changes occur in the city center to the southern part of the city of Cirebon. The results of multiple linear regression tests of land surface temperature are influenced by vegetation density and building density.
\end{abstract}

Keywords. Land Surface Temperature, Vegetation Index, Building Index

\section{Introduction}

The development of a city is essentially influenced by the growth and development of the population, where the city as a physical container of urban community activity [1]. Since the middle of the 20th century, human activity has been closely linked to global warming that occurred from observations of rising global average temperatures [2]. Land Surface Temperature (LST) is important role in the study of climate change on a local, regional and global scale [3]. Cirebon City is one of the cities in West Java Province which has an area of 3,735.82 hectares and located in a coastal area which makes Cirebon City has a wider land area than its hilly areas [4]. The development of the Cirebon region is one of the efforts of

\footnotetext{
* Corresponding author: cantikaliviona99@gmail.com
} 
the West Java Provincial Government to make development distribution in West Java carried out by the Government especially in the city of Cirebon by building access to the PalimananKanci / Cipali highway which is has connectivity in the capital cities of DKI Jakarta, Bandung and Semarang [5]. Therefore, the city of Cirebon has a relatively high connectivity where the cities cause a movement of people and goods to the city of Cirebon more quickly and more intensely [6]. Based on Central Bureau of Statistics City of Cirebon data, the population of Cirebon City continues to increase, in 2015 there were 307,494 people until the end of 2019 there were 319,312 people and estimated to increase by $0.7-1 \%$ every year. Increasing population, it will affect the area of land needed to support daily activities such as offices, industry, housing, shops and highways [7]. Based on data from the Department of Agriculture and Marine Fisheries (DPPKP) Cirebon City in 2017 the area of agricultural land is currently reduced to $246 \mathrm{Ha}$, which was previously agricultural land area of $264 \mathrm{Ha}$, it is due to land conversion. Expert on the function of vegetation land into non-vegetation can increase land surface temperature [8]. As a result of rising land surface temperatures can trigger climate change [9].

\section{Materials and Methods}

\subsection{Study Area}

This research was conducted in the city of Cirebon which is geographically located between $108^{\circ} 33$ East Longitude and $6^{\circ} 41$ South Latitude on the North coast of Java Island, the eastern part of West Java, extending from west to east $\pm 11 \mathrm{Km}$ with altitude from sea level $\pm 5 \mathrm{M}$ (including lowlands). Cirebon city has an area of 3,735.82 hectares or $\pm 37 \mathrm{~km} 2$ which consists of five subdistricts and 22 villages. The city of Cirebon is directly adjacent to Cirebon Regency and the Java Sea.

\subsection{Materials}

1. LST, NDVI and NDVI data obtained from Landsat-8 OLI/TIRS path 121 Row 64 recording May 202015 and Landsat-8 OLI / TIRS path 121 Row 64 recording November 7 (with $<10 \%$ cloud cover) obtained from downloads on the USGS (United State Geological Survey) website on the Geological Survey link) on the https://earthexplorer.usgs.gov/ link.

2. Shapefile of district and provincial level administrative boundaries in Indonesia (Source: Geospatial Information Agency).

\subsection{Methods}

Land Surface Temperature obtained from Landsat 8 Image OLI/TIRS processed in ArcGis 10.1. LST processing done by changing DN into RAD, change RAD to temperature (kelvin), and change temperature (kelvin) into temperature (Celsius). The process with tool raster calculator in ArcGis 10.1. Then classified according to the table 2.1.

Table 1 LST Classification

\begin{tabular}{|c|l|l|}
\hline No & LST Classification & Temperature \\
\hline 1. & Very Low & $<20^{\circ} \mathrm{C}$ \\
\hline 2. & Low & $20^{\circ} \mathrm{C}-25^{\circ} \mathrm{C}$ \\
\hline 3. & Medium & $25^{\circ} \mathrm{C}-30^{\circ} \mathrm{C}$ \\
\hline
\end{tabular}




\begin{tabular}{|c|l|l|}
\hline 4. & High & $30^{\circ} \mathrm{C}-35^{\circ} \mathrm{C}$ \\
\hline 5. & Very High & $>35^{\circ} \mathrm{C}$ \\
\hline
\end{tabular}

NDVI or vegetation density index is one method to measure the level of greenness of vegetation by comparing the spectral between NIR waves with red waves [10]. NDVI processing through calculations on the amount of radiation absorbed by plants in the PAR area (photosynthetically active radiation) or active radiation received by plants during photosynthesis. NDVI is obtained by using the following formula [11]:

NDVI Landsat $8=($ Band $5-$ Band 4$) /($ Band $5+$ Band 4$)$

Building density is seen based on the building density index by calculating with the NDBI formula. NDBI uses Landsat 8 Imagery with Band 5 and Band 6. The following NDBI formula:

$$
\text { NDBI Landsat } 8=(\text { Band } 6-\text { Band } 5) /(\text { Band } 6+\text { Band } 5)
$$

Statistical data processing is processed using SPSS software with multiple linear regression methods. Data taken from the results of image processing are, land surface temperature, vegetation density index value, and building density index value. Processing statistical data to determine the relationship between variables by looking at the significance of the $\mathrm{T}$ test and the $\mathrm{F}$ test. The $\mathrm{T}$ test to find out the independent variables (NDVI and NDBI) partially, significantly or not has effect on the dependent variable (LST). While the F test to determine the independent variables simultaneously (together) has a significant effect on the dependent variable.

\subsection{Data Analysis}

Land surface temperatures of the City of Cirebon in 2015 and 2019 were analyzed using a temporal spatial approach through the application of the map overlay method. Temporal spatial analysis aims to determine variations and patterns of land surface temperature. Variations and patterns of surface temperature are then analyzed by comparative descriptive to compare land surface temperatures based on a specified year. Statistical analysis of land surface temperature was also carried out to determine its relationship with the index (NDVI and NDBI) as the effect of increasing surface temperature.

\section{Result and Discussion}

\subsection{Land Surface Temperature}

The surface temperature of Cirebon City in 2015 ranged from $21.8^{\circ} \mathrm{C}-34.2^{\circ} \mathrm{C}$, included in the very low class - very high. In 2015 the city of Cirebon was dominated by high surface temperatures of $30^{\circ} \mathrm{C}-34^{\circ} \mathrm{C}$ with an area of $2,255 \mathrm{Ha}$. In the southern area of Cirebon City, the temperature is $26^{\circ} \mathrm{C}-30^{\circ} \mathrm{C}$ which is included in the medium class with an area of 1,557 Ha. In general, the LST pattern of Semarang City in 2015 follows the pattern of land cover. LST classes are following the pattern of vegetation land cover and water bodies such as in the southern region. Whereas the high class LST pattern follows the pattern of land cover in the built area (Fig. 1).

Based on data processing of Landsat 8 OLI / TIRS recording in 2019, the surface temperature of Cirebon City ranges from $25.7^{\circ} \mathrm{C}-39.1^{\circ} \mathrm{C}$, including in the low - very high class. In 2019 the city of Cirebon was dominated by very high land surface temperatures of more than $34^{\circ} \mathrm{C}$ with an area of $3,328 \mathrm{Ha}$. In the southern, northern and eastern regions close 
to the border of Cirebon Regency, the temperature is $30^{\circ} \mathrm{C}-34^{\circ} \mathrm{C}$ with an area of $456 \mathrm{Ha}$. In general, the surface temperature pattern of Cirebon City in 2019 follows the pattern of land cover. LST class is following the pattern of vegetation land cover. While the LST pattern is very high class following the pattern of land cover in the built area (Fig. 2).

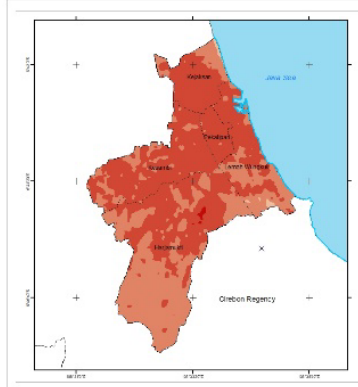

Fig. 1 LST 2015

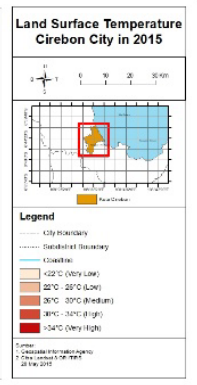
Fig. 2 LST 2019

Land surface temperature change from 2015 - 2019 experienced an increase in temperature in almost the entire region, especially in the section that spreads from the center of the City to the south. At the surface temperature of the land that does not change there is little in the east or coast of Cirebon (Fig. 3).

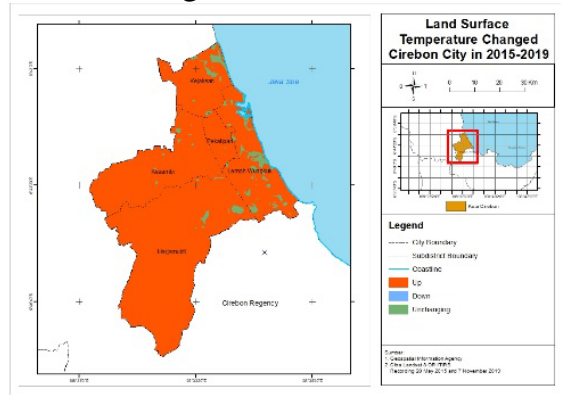

Fig. 3 LST Changed

\subsection{NDVI and NDBI}

In 2015 the city of Cirebon had a variety of vegetation densities. In the south is dominated by high vegetation density with a value of more than 0.42 . In contrast to the northern part of the city leading north the more diverse vegetation densities are nominated with a rare vegetation density class index of $0-0.32$. Whereas for the region the index value is less than 0 , namely the low vegetation area (Fig. 4).

In 2019 the whole area of Cirebon City is dominated by sparse vegetation density with a value of $0-0.32$ which is classified into sparse density class. In the south the vegetation density changes over time 2015 and 2019 from medium density to sparse and high density to medium density. This is related to the reduction of vegetation land into settlements in the south (Fig. 5). 

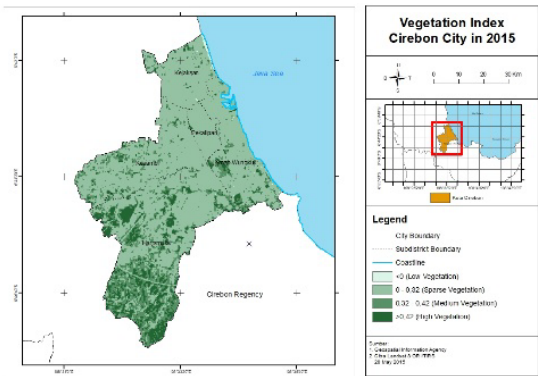

Fig. 4 NDVI 2015
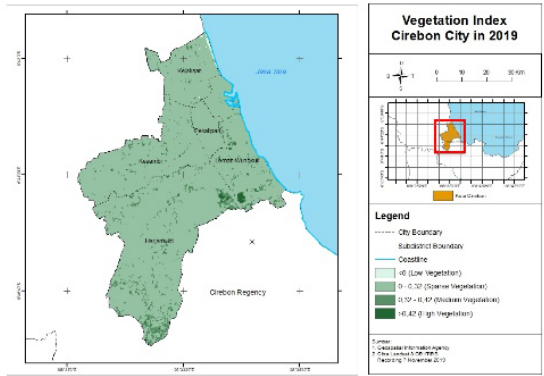

Fig. 5 NDVI 2019

Building density in 2015 is seen in the density of sparse settlements located in the city area towards the coast, with an index value of $0-0.1$ which is a residential area. While in the southern part there are non-residential areas with an index value of less than 0 (Fig. 6).

Building density in 2019 shows that Cirebon City is dominated by sparse building density with an index value of $0-0.1$ which is increasing from the city center to the south. Where in the southern part in 2015 was a non-settlement area which was transformed into a settlement area, this meant an increase in residential land in the southern region from vegetation to nonvegetation. Dense building density with an index value of $0.1-0.2$ also increases in the coastal area of Cirebon City (Fig. 7).

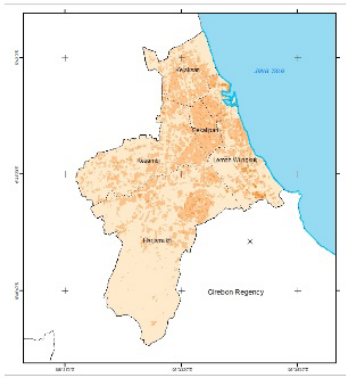

Fig. 6 NDBI 2015

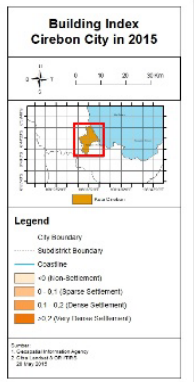
5 (1)
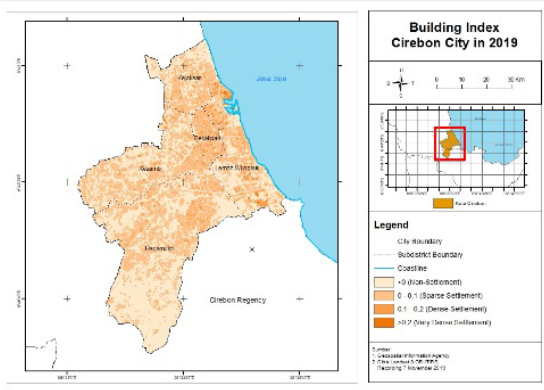

Fig. 7 NDBI 2019

\subsection{The effect of NDVI and NDBI on LST}

The relationship between land surface temperature and vegetation density and building density can be determined by passing a multiple linear regression test. In the multiple linear regression test the surface temperature of the land surface as the dependent variable (bound / Y), while there are two independent variables (free / X), namely vegetation density (X1) and building density (X2). Vegetation density and building density were obtained from the processing of Landsat 8 OLI / TIRS. The following hypotheses will be tested:

- $\quad \mathrm{H} 1$ = Variable density of vegetation has a significant effect on LST

- $\quad \mathrm{H} 2$ = building density variable has a significant effect on LST

- $\quad$ H3 = NDVI and NDBI variables have significant effect on LST

Table 2. Percentage of Relations

\begin{tabular}{|c|c|c|c|c|}
\hline Model & $\mathrm{R}$ & R Square & Adjusted R Square & $\begin{array}{l}\text { Std. Error of the } \\
\text { Estimate }\end{array}$ \\
\hline 1 & $.771^{\mathrm{a}}$ & .594 & .585 & 1.83963 \\
\hline
\end{tabular}

From the processing results obtained SUMMARY which shows the value of determination ( $\mathrm{R}$ Square) to determine the percentage contribution of the influence of the 
independent variable $(\mathrm{X})$ to the dependent variable $(\mathrm{Y})$. R Square value for the influence of land surface temperature with vegetation density and building density is 59,4\% (Table 2).

Simultaneously it can be seen from the F/ Anova test results. Based on the results of the significance value of the F test, obtained a value of 0,000 , then H3 is accepted. Means the density of vegetation and the density of buildings has a significant effect on land surface temperature (Table 3).

Table 3. Anova Test

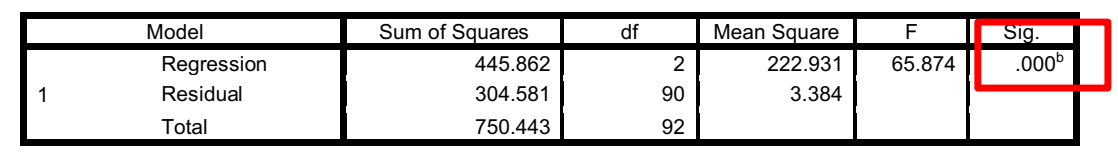

The partial relationship between variables $\mathrm{X}$ and $\mathrm{Y}$ can be seen from the significance value of the $t$ test. Based on the results of the $t$ test, the significance value of each variable is $\mathrm{X} 1$ (vegetation density) 0,000 and X2 (building density) 0,000 where the significance value of each variable is less than 0.05 then the hypotheses $\mathrm{H} 1$ and $\mathrm{H} 2$ are accepted. Therefore, the vegetation density and the building density both have a significant effect on the surface temperature of the City of Cirebon (Table 4).

Table 4. $t$ Test

\begin{tabular}{|c|c|c|c|c|c|c|}
\hline \multirow{2}{*}{\multicolumn{2}{|c|}{ Model }} & \multicolumn{2}{|c|}{ Unstandardized Coefficients } & \multirow{2}{*}{$\begin{array}{c}\frac{\text { Standardized Coefficients }}{\text { Beta }} \\
\end{array}$} & \multirow[t]{2}{*}{$T$} & \multirow[t]{2}{*}{ Sig. } \\
\hline & & $\mathrm{B}$ & Std. Error & & & \\
\hline \multirow{3}{*}{1} & (Constant) & 33.186 & .351 & & 94.446 & .000 \\
\hline & Vegetation Index & 15.291 & 1.748 & .736 & 8.747 & .000 \\
\hline & Building Index & 26.912 & 2.402 & .943 & 11.204 & .000 \\
\hline
\end{tabular}

\section{Conclusion}

Spatial surface temperature changes in the city of Cirebon spatially, have varying temperature changes. From 2015 to 2019 , the central part of the city tends to have high surface temperatures. Changes occur in the city center and lead to the south with very high surface temperatures. The increase in land surface temperature from 2015 to 2019 is considered a drastic increase. The highest surface temperature of Cirebon City from 2015-2019 was in the residential area. NDVI and NDBI together affect the surface temperature of $59.4 \%$. The higher the NDVI value, the surface temperature will be lower and the higher the NDBI value, the surface temperature will be higher. This shows that land cover affects land surface temperature.

\section{Acknowledgement}

The author would like to thank Directorate of Research and Community Service (DRPM) Universitas Indonesia, which has supported this research in Publikasi Terindeks Internasional (PUTI) Prosiding UI Year 2020 with contract number NKB-1037/UN2.RST/HKP.05.00/2020.

\section{References}

1. Al Mukmin S.A., Wijawa A.P., dan Sukmono A. Analisis Pengaruh Perubahan Tutupan Lahan Terhadap Distribusi Suhu Permukaan dan Keterkaitannya dengan Fenomena Urban Heat Island. Jurnal Geodesi Undip Volume 5, Nomor 1. (2016)

2. Andri N. Ardiansyah. Geography Perspectives in Understanding the Context of Climate Change. Sosio Didaktika: Social Science Education Journal, 2 (1), 2015, 67-75 (2015) 
3. BPS Cirebon City

4. Faizal, R. Identification of Changes in Land Use in Cirebon City Due to the Direct Access of the Cipali Toll Road. Thesis at Isam University Bandung (2018)

5. Hasdaniati, A. Study of Urban Development Patterns Based on Spatial Morphology in Bantaeng City. Thesis UIN Alauddin Makassar.Hasdaniati (2014)

6. IPCC. Climate Change (2007)

7. Mallick, J., Kant, Y., \& Bharath, B. D. Estimation of land surface temperature over Delhi using Landsat-7 ETM +. J. Ind. Geophys Union, 12 (3), 131-140 (2008)

8. Rahmi, J. Relationship between Headline Density and Land Use Based on Analysis of Satellite Imagery and GIS in Gunung Leuser National Park (Case Study of Tangakahan Resort Forest Area, Cinta Raja, Sei Lepan and Leuser Ecosystem Area). Forestry Department, Faculty of Agriculture, USU. (2009)

9. Sasky, P., Sobirin, \& Wibowo, A. The Effects of Changes in Land Use on Greater Surface Metropolitan Areas of Greater Bandung in 2000 - 2016. Industrial Research Workshop and National Seminar, 8, 354-361 (2017)

10. Tan, K. C., Lim, H. S., MatJafri, M. Z., \& Abdullah, K. Landsat data to evaluate urban expansion and determine land use / land cover changes in Penang Island, Malaysia. Environmental Earth Sciences, 60 (7), 1509-1521. (2010) 